\title{
Cadmium Uptake by Cucumber from Soil Amended with Phosphorus Fertilizers
}

\author{
B. Huang, S. Kuo, and R. Bembenek \\ Washington State University, Puyallup Research and Extension Center, 7612 Pioneer Way E., Puyallup, \\ WA 98371-4998
}

Additional Index words. Cucumis sativus, cadmium transfer efficiency, cadmium uptake, liming, yield

Abstract. Cadmium (Cd) concentrations in some phosphorus (P) fertilizers may be high enough to cause significant Cd accumulation in plants. A 2-year field experiment was conducted on a Sultan silt loam (Aquandic Xerochrept) to determine how the availability to cucumber (Cucumis sativus $\mathrm{L}_{\text {.) }}$ of $\mathrm{Cd}$ from a triple superphosphate (TSP) and a western phosphate rock (PR) was affected by rate of $\mathrm{Cd}$ input and liming. A water-soluble $\mathrm{Cd}_{\text {salt, }} \mathrm{CdCl}_{2}$, was included for comparison. Cucumber vine growth increased with increasing TSP application rates but was unaffected by the application of $\mathrm{PR}$ or $\mathrm{CdCl}_{2}$. Cucumber fruit yield, however, was unaffected by the application of either $\mathrm{P}$ fertilizer or $\mathrm{CdCl}_{2}$. Concentrations of $\mathrm{Cd}$ in cucumber vine or fruit responded to increased $\mathrm{Cd}$ inputs from $\mathbf{P R}$, TSP, or $\mathrm{CdCl}$, and the vine was the primary sink for $\mathrm{Cd}$ that accumulated in the plant. Both vine and fruit $\mathrm{Cd}$ correlated better with soil total Cd than with labile Cd extractable by $0.05 \mathrm{M} \mathrm{CaCl}_{2}$ or DTPA (diethylenetriaminepentaacetic acid). A unique characteristic of cucumber vine- or fruit- $\mathrm{Cd}$ is that it was unaffected $(P>0.05)$ by lime rate and $\mathrm{Cd}$ source and not closely related to labile or exchangeable $\mathrm{Cd}$ as measured by $0.05 \mathrm{M} \mathrm{CaCl}_{2}$, in contrast to previous findings for other vegetable or grain crops. Root exudates could have controlled the solubility of $\mathrm{Cd}$ in the soil. The low availability of $\mathrm{Cd}$ from these sources to the plant was evidenced by the low uptake coefficient of Cd $(0.461$ to 1.059$)$ from the soil to the cucumber fruit and low $\mathrm{Cd}$ recovery $(0.43 \%)$ in both vine and fruit of $\mathrm{Cd}$ added.

Cadmium (Cd) is one of the heavy metals potentially harmful to human health. It is readily available to plants and is not phytotoxic even at concentrations in crops that can increase human exposure to levels that cause health concerns (Adriano, 1986). Land disposal of municipal and industrial wastes that are used for their fertility benefits is an important pathway for the entry of $\mathrm{Cd}$ into soil (Wilson, 2001). Another pathway is the application of fertilizers for crop production. This is because some commercial phosphorus and trace element fertilizers contain elevated concentrations of Cd and other heavy metals (Mortvedt et al., 1981; Raven and Loeppert, 1997; Williams and David, 1973). Since only a small portion of the $\mathrm{Cd}$ added is removed by the crop, repeated applications of the fertilizers produce $\mathrm{Cd}$ input rates higher than the crop removal, which may lead to $\mathrm{Cd}$ accumulation in the soil (Nicholson and Jones, 1994). As a result, there are concerns as to the environmental and health risk from continued use of such fertilizers (McLaughlin et al., 1996).

Several studies have revealed a high availability of $\mathrm{Cd}$ in $\mathrm{P}$ fertilizers to plants. Reuss et al. (1978) found that the application of triple superphosphate (TSP) increased $\mathrm{Cd}$ accumulation in radish (Raphanus sativus L.), lettuce (Latuca sativa L.), and peas (Pisum sativum L.). Other investigators also found a significant increase in Cd uptake by grain and vegetable crops following additions of NPK fertilizers to soil (He and Singh, 1994; Grant and Bailey, 1998; Guttormsen et al., 1995). However, there are also findings contradicting these results. Mortvedt et al. (1981) and Mortvedt (1985) showed no significant increase in Cd concentrations in winter wheat (Triticum aestivum L.) or immature corn (Zea mays L.) with normal application rates of TSP containing Cd up to 153 $\mathrm{mg} \cdot \mathrm{kg}^{-1}$ or of $\mathrm{Zn}$ fertilizers containing Cd up to $2165 \mathrm{mg} \cdot \mathrm{kg}^{-1}$. Whether or not application of a fertilizer will lead to an increase in plant accumulation of $\mathrm{Cd}$ may hinge upon factors including input rates of $\mathrm{Cd}$ from fertilizers, its solubility, and type of plant species involved (Grant et al., 1998).

Received for publication 15 July 2002. Accepted for publication 26 Feb. 2003 Scientific Paper 0205-02, Department of Crop and Soil Sciences, College of Agriculture and Home Economics, Washington State University, Pullman.
Most studies that examined the availability to crops of $\mathrm{Cd}$ from fertilizers focus on grain (Grant and Bailey, 1998; Mortvedt et al., 1981; Mortvedt, 1985; Mortvedt, 1987; Mulla et al., 1980) and leafy vegetable crops (He and Singh, 1994; Kim et al., 1988; Reuss et al., 1978). Little research has been done on the availability of $\mathrm{Cd}$ from fertilizers to cucumber. The few studies that determined uptake of $\mathrm{Cd}$ from biosolids by cucumber under greenhouse conditions showed the uptake was not influenced by $\mathrm{pH}$ (Falahi-Ardakani et al., 1988), but was affected by Cd concentrations in the growing medium (Moreno-Caselles et al., 2000; Obata and Umebayashi 1997; Tack et al., 1998). The applicability of these findings to fertilizer $\mathrm{Cd}$ is uncertain, especially under field conditions.

The objectives of this 2-year field study were to determine 1) the influence of liming on the accumulation in cucumber vine and fruit of $\mathrm{Cd}$ from a western phosphate rock (PR) or a TSP; 2 ) which index of soil $\mathrm{Cd}$ availability best predicts $\mathrm{Cd}$ concentrations in cucumber vine or fruit; and 3 ) the recovery of added $\mathrm{Cd}$ from the fertilizers in cucumber vine and fruit. A readily soluble $\mathrm{Cd}$ salt, $\mathrm{CdCl}_{2}$, was included for comparison. The higher than normal application rates of the fertilizers used in this study helped determine the transfer efficiency and recovery in cucumber of $\mathrm{Cd}$ applied from the fertilizers.

\section{Materials and Methods}

This 2-year experiment was conducted on a Sultan silt loam at a Washington State University research farm near Puyallup, Wash. This soil is classified as fine-silty, mixed, mesic Aquandic Xerochrept. Treatments included three $\mathrm{Cd}$ sources (a western phosphate rock, a triple superphosphate, and $\mathrm{CdCl}_{2}$ ), five application rates of $\mathrm{Cd}$ for each $\mathrm{Cd}$ source, and two lime rates. The total $\mathrm{Cd}$ concentrations were $40.9 \mathrm{mg} \cdot \mathrm{kg}^{-1}$ for the PR and 125.1 $\mathrm{mg} \cdot \mathrm{kg}^{-1}$ for the TSP (Kuo et al., 2001). The Cd concentrations were determined by digesting $1 \mathrm{~g}$ of each fertilizer in $20 \mathrm{~mL}$ of aqua regia overnight at room temperature, followed by analysis of Cd by flame atomic absorption spectrophotometry (AAS) with Deuterium arc background correction. 
In Sept. 1998, part of the experimental site was limed with $\mathrm{CaCO}_{3}$ at the rate of $4.4 \mathrm{Mg} \cdot \mathrm{ha}^{-1}$, which raised soil $\mathrm{pH}$ from 5.3 to $\approx 6.7$. Lime was surface applied with a drop spreader and disked in. This was followed by applications of PR, TSP, and $\mathrm{CdCl}_{2}$ with a drop spreader and incorporation into the soil using a rototiller to a depth of $\approx 12 \mathrm{~cm}$. $\mathrm{CdCl}_{2}$ was mixed with silica sand before application because of the small quantity of $\mathrm{CdCl}_{2}$ used. The five application rates for the fertilizers were $0,1 \times, 2 \times$, $4 \times$, and $8 \times$, with the $1 \times$ rate being $645 \mathrm{~kg} \cdot \mathrm{ha}^{-1}$ for PR and 430 $\mathrm{kg} \cdot \mathrm{ha}^{-1}$ for TSP, which added $\mathrm{Cd}$ at 26.4 and $53.8 \mathrm{~g} \cdot \mathrm{ha}^{-1}$ for PR and TSP, respectively. The $1 \times$ rate of $\mathrm{Cd}$ for $\mathrm{CdCl}_{2}$ was $90 \mathrm{~g} \cdot \mathrm{ha}-$ ${ }^{1}$, the maximum allowable annual $\mathrm{Cd}$ input in Washington State (Washington State Department of Agriculture, 2000). The $1 \times$ rate for PR and TSP is the maximum allowable application rate of the fertilizers in a given year, as promulgated by the Washington State Dept. of Agr. Each treatment was replicated four times using a split-plot design. The size of each plot was $4.6 \times 7.6 \mathrm{~m}$, with a 3-m alley between plots. Cucumber was not planted until the following spring of each year. This allowed the added $\mathrm{Cd}$ from the fertilizers or $\mathrm{CdCl}_{2}$ to equilibrate with the soil over winter.

The fertilizers and $\mathrm{CdCl}_{2}$ were reapplied in Sept. 1999. This brought the cumulative application rates to $0,2 \times, 4 \times, 8 \times$, and $16 \times$ for the year 2000 study. The $1 \times$ rate for each fertilizer and $\mathrm{CdCl}_{2}$ was the same as defined above.

The field was treated with glyphosate at $2.5 \mathrm{~L} \cdot \mathrm{ha}^{-1}$ in Spring 1999 and $2000, \approx 2$ months before planting. This was followed by uniform applications of $370 \mathrm{~kg} \cdot \mathrm{ha}^{-1}$ of KCl, $135 \mathrm{~kg} \cdot \mathrm{ha}^{-1}$ of KMAG $(17.4 \% \mathrm{~K}, 10 \% \mathrm{Mg}$, and $21 \% \mathrm{~S})$, and $22 \mathrm{~kg} \cdot \mathrm{ha}^{-1}$ of micronutrient $\operatorname{mix}(8 \% \mathrm{~S}, 1.5 \% \mathrm{~B}, 1.5 \% \mathrm{Cu}, 3 \% \mathrm{Mg}$, and $6 \% \mathrm{Zn})$. The KMAG contained $0.78 \mathrm{mg} \cdot \mathrm{kg}^{-1} \mathrm{Cd}$, and the micronutrient mix contained $10.5 \mathrm{mg} \cdot \mathrm{kg}^{-1} \mathrm{Cd}$. The total input of $\mathrm{Cd}$ to the soil from the applications of these fertilizers $\left(0.4 \mathrm{~g} \cdot \mathrm{ha}^{-1}\right)$ was very small, $<1.5 \%$ of $\mathrm{Cd}$ added from PR or TSP at the lowest (1x) rate. The fertilizers were all incorporated into soil with a rototiller.

Cucumber (Cucumis sativa L.) 'Calypso' was planted in June 1999 and June 2000 with a row spacing of $81 \mathrm{~cm}$ and a seeding rate of 194,000 seeds/ha. A uniform band application of $22 \mathrm{~kg} \cdot \mathrm{ha}^{-1} \mathrm{~N}$ and $50 \mathrm{~kg} \cdot \mathrm{ha}^{-1} \mathrm{P}$ as $11-52-0$ (mono-ammonium phosphate), $5 \mathrm{~cm}$ away and $5 \mathrm{~cm}$ below the seed, was made at the time of seeding. A month after seeding, cucumbers were sidedressed with $80 \mathrm{~kg} \cdot \mathrm{ha}^{-1}$ $\mathrm{N}$ as $\mathrm{NH}_{4} \mathrm{NO}_{3}$. The concentration of $\mathrm{Cd}$ in the mono-ammonium phosphate fertilizer soluble in aqua regia was low, $1.51 \mathrm{mg} \cdot \mathrm{kg}^{-1}$ $\mathrm{Cd}$, and total $\mathrm{Cd}$ added from its application was $<1.2 \%$ of the $\mathrm{Cd}$ added from the PR or TSP at the lowest $(1 \times)$ rate.

For weed control during the growing season, the field was mechanically cultivated with a field cultivator until the plant canopy had developed to an extent that covered more than onethird of the space between two adjacent rows. Thereafter, the cultivation was done manually. Irrigation via sprinkler irrigation was applied periodically to maintain adequate soil moisture for plant growth.

Nine to ten weeks after planting, cucumber plants from 1.52 $\mathrm{m}$ of row in the center of each plot were cut just above soil surface. Fruit and vines were separated, and their fresh weights were determined. All plant tissues were washed twice with tap water and once with deionized water. Vines and cut fruit were air-dried first in a heated greenhouse $\left(\approx 31^{\circ} \mathrm{C}\right)$ for $48 \mathrm{~h}$ to reduce mass and volume before oven drying at $65^{\circ} \mathrm{C}$ for $72 \mathrm{~h}$ for dry weight determination. The dry vine or fruit tissue was ground to $<1 \mathrm{~mm}$ using a stainless steel grinder. For chemical analysis, $1.0 \mathrm{~g}$ of ground plant tissue was ashed in a muffle furnace at 500 ${ }^{\circ} \mathrm{C}$ (Chaney et al., 1982) for $12 \mathrm{~h}$, followed by digestion in 10
mL of concentrated $\mathrm{HNO}_{3}$ at 80 to $90{ }^{\circ} \mathrm{C}$ until dry. Residue was dissolved in $10 \mathrm{~mL}$ of $1.2 \mathrm{~m} \mathrm{HCl}$ for $\mathrm{Cd}$ analysis by AAS with Deuterium arc background correction. The sensitivity for $\mathrm{Cd}$ determination was $0.025 \mathrm{mg} \cdot \mathrm{L}^{-1}$.

Soil samples were taken to a depth of $15 \mathrm{~cm}$ from the same area where the cucumber was harvested in each plot. Six cores were taken and mixed well. The soil was air-dried and crushed to pass a 2-mm sieve before chemical analysis.

Chemical analysis of the soil included $\mathrm{pH}$ (1 soil : 2 water), total $\mathrm{Cd}$ and the amount of Cd extractable by DTPA (diethylenetriaminepentaacetic acid) or $0.05 \mathrm{M} \mathrm{CaCl}_{2}$, and the amount of $\mathrm{P}$ extractable by $\mathrm{NaHCO}_{3}$. For total Cd determination, U.S. EPA method 3050 (USEPA, 1986) was used. Two grams of soil were digested in $20 \mathrm{~mL}$ of $1: 1 \mathrm{HNO}_{3}$ and water in a beaker covered with a watch glass on a hot plate for $15 \mathrm{~min}$ without boiling. The solution was allowed to cool before being digested twice in 10 $\mathrm{mL}$ of concentrated $\mathrm{HNO}_{3}$ for $30 \mathrm{~min}$ in each digestion. After the volume of the solution was evaporated down to 2 to $3 \mathrm{~mL}$, it was digested on a hot plate again with $3 \mathrm{~mL}$ of $\mathrm{H}_{2} \mathrm{O}_{2}(30 \%)$ three or more times until the solution was clear. The solution was then digested with $2.5 \mathrm{~mL}$ of concentrated $\mathrm{HCl}$ for $15 \mathrm{~min}$, filtered into a $25-\mathrm{mL}$ volumetric flask through a $5-\mu \mathrm{m}$ filter paper after it was cooled, and brought to volume with deionized water. The filtrate was analyzed for Cd by AAS.

The extractable $\mathrm{Cd}$ in the soil was determined by extracting the soil with $0.005 \mathrm{~m}$ DTPA ( $\mathrm{pH}=7.3)(1: 2$ soil to solution ratio, $2 \mathrm{~h}$ extraction time) or $0.05 \mathrm{M} \mathrm{CaCl}_{2}(1: 2$ soil to solution ratio, 30 min extraction time). The suspension was centrifuged for 10 min at $1500 \mathrm{~g}_{\mathrm{n}}$, followed by filtration through a filter paper (pore size $5 \mu \mathrm{m}$ ) to remove any suspended organic debris, before being analyzed for $\mathrm{Cd}$ by AAS. The $\mathrm{NaHCO}_{3}$-extractable $\mathrm{P}$ was determined by extracting the soil with $0.5 \mathrm{M} \mathrm{NaHCO}_{3}(\mathrm{pH}=8.5)$ (1:20 soil to solution ratio, 30 min extraction time), followed by analysis of P by the method of Murphy and Riley (1962).

Quality control was performed using standard reference materials (National Institute of Standards and Technology [NIST], Gaitherberg, Md.). The analytical results were compared with the certified values for the standard reference materials. The reference materials included spinach leaves (NIST \#1570) and San Joaquin soil (NIST \#2709). The determined value for the spinach leaves was $2.69 \pm 0.32 \mu \mathrm{g} \cdot \mathrm{g}^{-1} \mathrm{Cd}$ as compared to the certified values of $2.89 \pm 0.07 \mu \mathrm{g} \cdot \mathrm{g}^{-1} \mathrm{Cd}$. The determined value for the soil was $0.52 \pm 0.01 \mathrm{mg} \cdot \mathrm{kg}^{-1} \mathrm{Cd}$, which is slightly higher than the certified value of $0.38 \pm 0.01 \mathrm{mg} \cdot \mathrm{kg}^{-1} \mathrm{Cd}$.

Analysis of variance was performed using the GLM procedure in Statistical Analysis System (SAS Institute, 1989). Mean separations were performed using Duncan's Multiple Range Test. Linear regression analyses were performed for determining the relationship between soil total $\mathrm{Cd}$ and the amount of labile $\mathrm{Cd}$ extractable by DTPA or $\mathrm{CaCl}_{2}$, and the relationship between concentrations of $\mathrm{Cd}$ in the harvested plant tissue and soil total $\mathrm{Cd}$ or labile $\mathrm{Cd}$.

\section{Results and Discussion}

CuCUMber Vine AND FRUIT YiELDS. The vine dry matter yield (DMY) in each year significantly responded to increasing application rates of TSP, but not to increasing rates of PR (Table 1). The average vine DMY across lime rates increased from 1281 in the control to $1901 \mathrm{~kg} \cdot \mathrm{ha}^{-1}$ at the $8 \times$ rate in 1999 and from 2128 to $2777 \mathrm{~kg} \cdot \mathrm{ha}^{-1}$ at the $16 \times$ rate on a cumulative basis in 2000 for TSP (Table 1). The yield averaged across all fertilizer and $\mathrm{CdCl}_{2}$ 
Table 1. Dry matter yields (DMY) of cucumber vine and fruit averaged across lime treatments as affected by application of different fertilizers varying in Cd concentration in 1999 and 2000.

\begin{tabular}{|c|c|c|c|c|c|c|c|}
\hline \multicolumn{4}{|c|}{1999} & \multicolumn{4}{|c|}{2000} \\
\hline $\begin{array}{l}\text { Fertilizer } \\
\text { rate }\end{array}$ & $\begin{array}{c}\mathrm{Cd} \\
\text { added } \\
\left(\mathrm{g} \cdot \mathrm{ha}^{-1}\right)\end{array}$ & $\begin{array}{c}\text { Vine } \\
\text { DMY } \\
\left(\mathrm{kg} \cdot \mathrm{ha}^{-1}\right)\end{array}$ & $\begin{array}{c}\text { Fruit } \\
\text { DMY } \\
\left(\mathrm{kg} \cdot \mathrm{ha}^{-1}\right)\end{array}$ & $\begin{array}{l}\text { Fertilizer } \\
\text { rate }\end{array}$ & $\begin{array}{c}\mathrm{Cd} \\
\text { added } \\
\left(\mathrm{g} \cdot \mathrm{ha}^{-1}\right)\end{array}$ & $\begin{array}{c}\text { Vine } \\
\text { DMY } \\
\left(\mathrm{kg} \cdot \mathrm{ha}^{-1}\right)\end{array}$ & 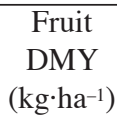 \\
\hline \multicolumn{8}{|l|}{$\overline{\mathrm{PR}}$} \\
\hline $0 \times$ & 0 & $1281 \mathrm{a}^{\mathrm{z}}$ & $1052 \mathrm{a}$ & $0 \times$ & 0 & $2128 \mathrm{a}$ & 997 a \\
\hline $1 \times$ & 25.8 & $1179 \mathrm{a}$ & $1097 \mathrm{a}$ & $2 x$ & 51.6 & $2090 \mathrm{a}$ & 1129 a \\
\hline $2 x$ & 51.6 & $1369 \mathrm{a}$ & $1018 \mathrm{a}$ & $4 x$ & 103.2 & $2152 \mathrm{a}$ & $1140 \mathrm{a}$ \\
\hline $4 \times$ & 103.2 & $1115 \mathrm{a}$ & $883 \mathrm{a}$ & $8 x$ & 206.4 & $2197 \mathrm{a}$ & $1007 \mathrm{a}$ \\
\hline $8 x$ & 206.4 & $1222 \mathrm{a}$ & $1033 \mathrm{a}$ & $16 x$ & 412.8 & $1962 \mathrm{a}$ & $1252 \mathrm{a}$ \\
\hline Rate & & NS & NS & Rate & & NS & NS \\
\hline Lime & & NS & NS & Lime & & $* *$ & NS \\
\hline Rate $\times$ lime & & NS & NS & Rate $\times \operatorname{lin}$ & & NS & NS \\
\hline \multicolumn{8}{|l|}{ TSP } \\
\hline $0 \times$ & 0 & $1281 \mathrm{c}$ & $1052 \mathrm{a}$ & $0 \times$ & 0 & $2128 \mathrm{~b}$ & 997 a \\
\hline $1 \times$ & 53.8 & $1410 \mathrm{bc}$ & $1177 \mathrm{a}$ & $2 x$ & 107.5 & $2444 \mathrm{ab}$ & $1140 \mathrm{a}$ \\
\hline $2 x$ & 107.5 & $1543 \mathrm{~b}$ & 1159 a & $4 x$ & 215.0 & $2441 \mathrm{ab}$ & $1258 \mathrm{a}$ \\
\hline $4 \times$ & 215.0 & $1531 \mathrm{~b}$ & $1336 \mathrm{a}$ & $8 x$ & 430.0 & $2740 \mathrm{a}$ & $1173 \mathrm{a}$ \\
\hline $8 x$ & 430.0 & $1901 \mathrm{a}$ & $1200 \mathrm{a}$ & $16 x$ & 860.0 & $2777 \mathrm{a}$ & 973 a \\
\hline Rate & & $* * *$ & NS & Rate & & $* *$ & NS \\
\hline Lime & & NS & $*$ & Lime & & $*$ & NS \\
\hline Rate $\times$ lime & & NS & NS & Rate $\times$ lin & & NS & NS \\
\hline \multicolumn{8}{|l|}{$\mathrm{CdCl}_{2}$} \\
\hline $0 \times$ & 0 & $1281 \mathrm{a}$ & $1052 \mathrm{a}$ & $0 \times$ & 0 & $2128 \mathrm{a}$ & $997 \mathrm{a}$ \\
\hline $1 \times$ & 90 & $1066 \mathrm{~b}$ & 886 a & $2 x$ & 180.0 & 2079 a & $1071 \mathrm{a}$ \\
\hline $2 x$ & 180 & $1159 \mathrm{ab}$ & $884 \mathrm{a}$ & $4 x$ & 360.0 & $2005 \mathrm{a}$ & $1234 \mathrm{a}$ \\
\hline $4 \times$ & 360 & $1047 \mathrm{~b}$ & $805 \mathrm{a}$ & $8 x$ & 720.0 & $1910 \mathrm{a}$ & $1058 \mathrm{a}$ \\
\hline $8 \times$ & 720 & $1182 \mathrm{ab}$ & 892 a & $16 x$ & 1440.0 & $1961 \mathrm{a}$ & 1089 a \\
\hline Rate & & $*$ & NS & Rate & & NS & NS \\
\hline Lime & & NS & $*$ & Lime & & $* * *$ & NS \\
\hline Rate $\times$ lime & & NS & NS & Rate $\times \operatorname{lin}$ & & NS & NS \\
\hline
\end{tabular}

zValues in same column for same testing treatment followed by a different letter are significantly different $(P<0.05)$, Duncan's new range test. ss,*,**,*** Nonsignificant or significant at $P=0.05,0.01,0.001$, respectively.

treatments was higher in $2000\left(2209 \mathrm{~kg} \cdot \mathrm{ha}^{-1}\right)$ than in 1999 (1304 $\mathrm{kg} \cdot \mathrm{ha}^{-1}$ ), possibly due to the earlier planting date in 2000 (June 2) than in 1999 (June 14).

The significant correlation of vine DMY with $\mathrm{NaHCO}_{3}$-P over the broad range of $\mathrm{NaHCO}_{3}$-P test values in $1999(r=0.74, P$ $<0.001)$ or $2000(r=0.63, P<0.01)$ reflected a relatively high $\mathrm{P}$ requirement for vine growth (Fig. 1). The amount of labile $\mathrm{P}$ extractable by $\mathrm{NaHCO}_{3}$ increased $\mathrm{P}$ from 38.2 in the control to $127.5 \mathrm{mg} \cdot \mathrm{kg}^{-1}$ at the $8 \times$ rate of TSP in 1999 for the unlimed soil. $\mathrm{P}$ was further raised to $147.1 \mathrm{mg} \cdot \mathrm{kg}^{-1}$ at the $16 \times$ rate of TSP on a cumulative basis for the unlimed soil in 2000 . In contrast, the $8 \times$ rate of PR in 1999 and the $16 \times$ rate on a cumulative basis in 2000 raised $\mathrm{NaHCO}_{3}-\mathrm{P}$ levels only to 45.6 or $48.6 \mathrm{mg} \cdot \mathrm{kg}^{-1}$, respectively. Inability of the added PR to increase vine DMY is not surprising, given the small increase in the $\mathrm{NaHCO}_{3}-\mathrm{P}$ test values produced by the additions of PR. The PR is sparingly soluble even in moderately acidic soil (Armiger and Fried, 1957), unless acidulated before application (Iretskaya et al., 1998).

The $\mathrm{CdCl}_{2}$ treatments had either a marginal or no effect on vine DMY, depending on the year (Table 1). No reduction in vine DMY occurred even with higher $\mathrm{CdCl}_{2}$ additions in 2000. Cucumber vine DMY was not correlated with $\mathrm{Cd}$ additions in either year $\left(r^{2}\right.$ $<0.01, P>0.05$ ). Liming did not consistently benefit vine DMY Only in 2000 was the response to liming statistically significant at $P=0.05$ (Table 1).

Unlike cucumber vine, cucumber fruit yield was unaffected
$(P>0.05)$ by TSP regardless of the rate (Table 1$)$. The increased vine growth with increasing TSP rates did not increase total fruit yield. Liming benefited fruit yield only for TSP and $\mathrm{CdCl}_{2}$ treatments in 1999.

Concentrations of CD in CuCUMber Vine and Fruit. Concentration of $\mathrm{Cd}$ in cucumber vine (vine $\mathrm{Cd}$ ) ranged from 1.00 to $2.09 \mathrm{mg} \cdot \mathrm{kg}^{-1}$, depending on the amount and source of $\mathrm{Cd}$, and year (Figs. 2 and 3). Soil total $\mathrm{Cd}$ and vine or fruit $\mathrm{Cd}$ were significantly correlated irrespective of Cd source. Except for the marginal effect of liming on vine Cd for TSP treatments and on fruit Cd for PR treatments in 1999, liming generally had no effect on vine or fruit $\mathrm{Cd}$ for other $\mathrm{Cd}$ sources in 1999 or all Cd sources in 2000. Insensitivity of $\mathrm{Cd}$ accumulation by cucumber to $\mathrm{pH}$ was also found by Falahi-Ardakani et al. (1988) in a greenhouse study using biosolids as a Cd source. Lack of a $\mathrm{pH}$ influence on cucumber vine $\mathrm{Cd}$ and fruit $\mathrm{Cd}$ is in sharp contrast to what had been found for many other crops. The accumulation of $\mathrm{Cd}$ by vegetable, grain and other crops often is influenced by soil $\mathrm{pH}$ (Bell et al., 1991; Heckman et al., 1987; Mortvedt et al., 1981). Soil $\mathrm{pH}$ was anticipated to play an intimate role in controlling $\mathrm{Cd}$ availability to the plant, given its known ability to control $\mathrm{Cd}$ sorption by soils and the concentration or activity of $\mathrm{Cd}$ in soil solution (Eriksson, 1990; Kuo et al., 1985).

The slope of the response of vine or fruit $\mathrm{Cd}$ to increased soil total Cd did not vary significantly $(P>0.05)$ among the $\mathrm{Cd}$ sources (Table 2), despite a marked difference in the lability of 


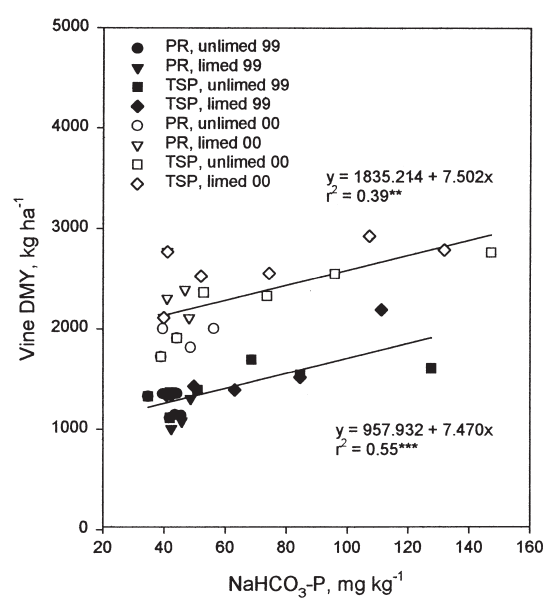

Fig 1. Relationship between soil labile Pextracted by $\mathrm{NaHCO}_{3}$ test and cucumber vine dry matte yield (DMY) in 1999 and 2000 in the limed and unlimed soi amended with phosphate rock (PR) or triple superphosphate (TSP).

their Cd that followed the following order: soluble Cd salt > TSP > PR (Kuo et al., 2001). It appears that as with $\mathrm{pH}$, the lability of $\mathrm{Cd}$ in these $\mathrm{Cd}$ sources played no significant role in the accumulation of $\mathrm{Cd}$ by cucumber vine or fruit. This result raises the possibility that the solubility of $\mathrm{Cd}$ in soil solution was controlled predominately by cucumber exudates, rather than $\mathrm{pH}$ or Cd source. Plant exudates can modify the mobility of $\mathrm{Cd}$ or other elements in the soil rhizosphere and increase plant uptake of Cd (Krishnamurti et al., 1997; Mench and Martin, 1991). Further research is needed to clarify if cucumber plant roots regulate the solubility of $\mathrm{Cd}$ in soil solution.

The correlation of vine or fruit $\mathrm{Cd}$ with soil total $\mathrm{Cd}$ over all $\mathrm{Cd}$ sources at each lime rate was, in general, better than that with the labile $\mathrm{Cd}$ extractable by DTPA or $\mathrm{CaCl}_{2}$ in 1999 (Fig. 4) or 2000 (Fig. 5). Across all Cd sources and lime rates, the correlation was best with soil total Cd, intermediate with DTPA-Cd and least with $\mathrm{CaCl}_{2}-\mathrm{Cd}$. This is a result opposite to what has been found for other crops including lettuce, maize, wheat, and spinach (Spinacia oleracea L.) (Kuo et al., 2001; Mortvedt et al., 1981; Smilde et al., 1992). Unlike soil total Cd, DTPA-Cd is moderately and $\mathrm{CaCl}_{2}-\mathrm{Cd}$ highly sensitive to soil $\mathrm{pH}$ and $\mathrm{Cd}$ source (Kuo et al., 2001; Singh et al., 1995). For example, the concentration of $\mathrm{CaCl}_{2}-\mathrm{Cd}$ for the soil treated with $\mathrm{CdCl}_{2}$ at the rate of $16 \times$ in the year 2000 decreased from $0.266 \pm 0.055 \mathrm{mg} \cdot \mathrm{kg}^{-1} \mathrm{Cd}$ in the unlimed soil to $0.027 \pm 0.003 \mathrm{mg} \cdot \mathrm{kg}^{-1} \mathrm{Cd}$ in the limed soil. This compared with the reduction of DTPA-Cd from $0.580 \pm 0.049 \mathrm{mg} \cdot \mathrm{kg}^{-1} \mathrm{Cd}$ in the unlimed soil to $0.390 \pm 0.066 \mathrm{mg} \cdot \mathrm{kg}^{-1} \mathrm{Cd}$ in the limed soil. For plant $\mathrm{Cd}$ such as vine- or fruit-Cd that does not vary significantly with $\mathrm{pH}$ and $\mathrm{Cd}$ source, its concentration is better predicted by soil total $\mathrm{Cd}$ than by DTPA- or $\mathrm{CaCl}_{2}-\mathrm{Cd}$.

CADMIUM UPTAKe BY CUCUMBER VINE AND FRUIT. The total amount of $\mathrm{Cd}$ accumulated in the aboveground biomass, including vine and fruit, in the control treatment was very small, averaging 1.65 and $2.95 \mathrm{~g} \mathrm{ha}^{-1}$ across lime rates for 1999 and 2000, respectively. While it increased with increasing amounts of $\mathrm{Cd}$ added from the $\mathrm{P}$ fertilizers and $\mathrm{CdCl}_{2}$ (Figs. 6 and 7), the total accumulated represented a very small fraction $(<0.33 \%)$ of the total $\mathrm{Cd}$ added. Increased $\mathrm{Cd}$ accumulation in the soil will occur if $\mathrm{P}$ fertilizer is applied at high rates that add more $\mathrm{Cd}$ than is removed by harvested cucumber biomass over a long period of time.

Of the total amount of $\mathrm{Cd}$ accumulated in the aboveground biomass in the control, most (78.6\%) accumulated in the vine, which agrees with the finding of Falahi-Ardakani et al. (1988) that cucumber vine is the primary sink for $\mathrm{Cd}$ in the plant. The translocation of $\mathrm{Cd}$ from vine to fruit was limited.

The proportion of total $\mathrm{Cd}$ in the plant residing in the vine did not vary with rate of $\mathrm{Cd}$ addition or with $\mathrm{Cd}$ source. It was affected minimally by liming as well. Averaged over all Cd rates and sources, the proportion of total $\mathrm{Cd}$ in the plant residing in the vine was $77.5 \%$ in 1999 and $78.7 \%$ in 2000 for the unlimed soil as compared to $78.9 \%$ in 1999 and $82.7 \%$ in 2000 for the limed soil. Thus, the net amount of $\mathrm{Cd}$ removed from the soil is even lower than $0.1 \%$ of the $\mathrm{Cd}$ added if the cucumber vine is left in the soil as it often is. Under these circumstances, even more of the added $\mathrm{Cd}$ will accumulate in the soil.

Cadmium uptake COEFficient (UC). The UC for Cd [UC(Cd)] of a metal describes the extent to which soil $\mathrm{Cd}$ is transferred from soil to plant. The UC for Cd essentially is the slope of the regression of vine- or fruit-Cd against soil total Cd (Figs. 2 and $3)$. The $\mathrm{UC}(\mathrm{Cd})$ for cucumber vine or fruit was unaffected $(P>$ 0.05 ) by $\mathrm{Cd}$ source or lime rate (Table 2 ). Over all $\mathrm{Cd}$ sources and lime rates, the $\mathrm{UC}(\mathrm{Cd})$ averaged 1.92 in 1999 and 1.60 in 2000 for vine and 0.79 in 1999 and 0.72 in 2000 for fruit. The UC(Cd) for cucumber fruit is comparatively lower than that for such leafy vegetables as lettuce (ranging from 1.28 to 15.9) (Crews and Davies, 1985; Kuo et al., 2001; Smilde et al., 1992) and spinach (1.36 to 21.06) (Smilde et al., 1992) that are known to be high $\mathrm{Cd}$ accumulators. Cucumber is unique in that the typical effect of $\mathrm{Cd}$ source and $\mathrm{pH}$ on $\mathrm{UC}(\mathrm{Cd})$ for lettuce, spinach or other vegetable crops (Bell et al., 1991; Kiekens et al., 1984; Kuo et
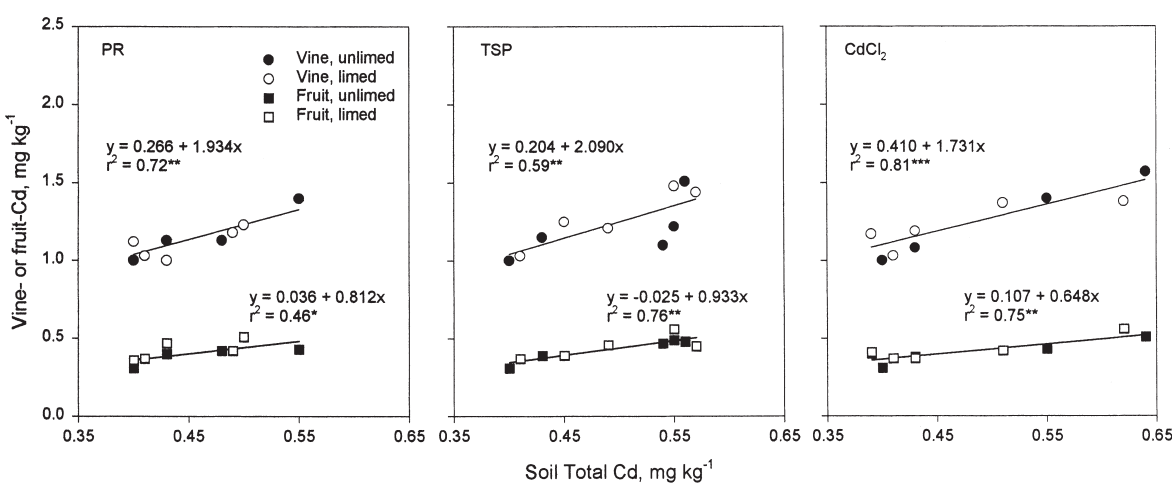

Fig 2. Concentrations of $\mathrm{Cd}$ in cucumber vine and fruit as affected by soil total $\mathrm{Cd}$ and liming in the soil amended with phosphate rock (PR), triple superphosphate (TSP), or $\mathrm{CdCl}_{2}$ in 1999 .
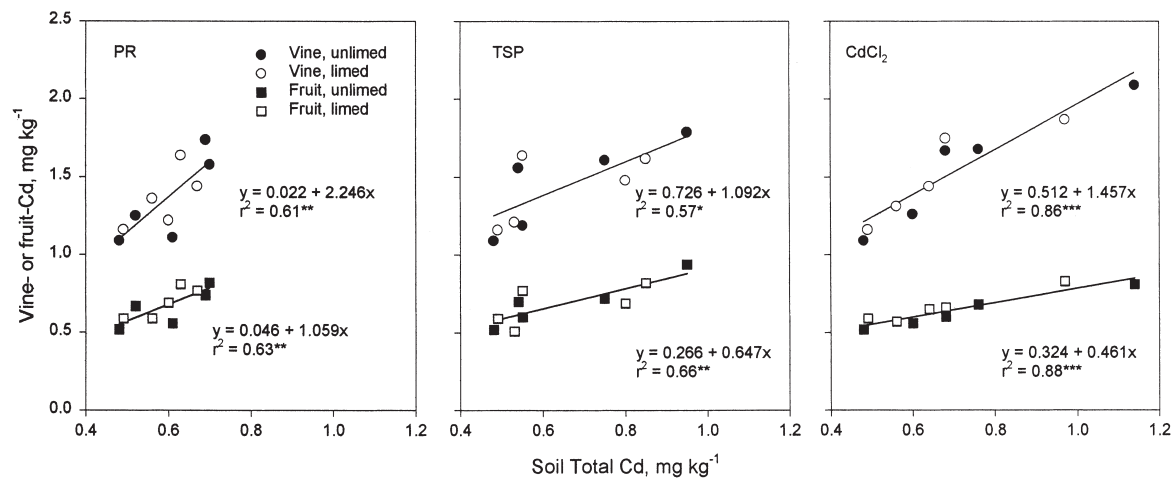

Fig 3. Concentrations of $\mathrm{Cd}$ in cucumber vine and fruit as affected by soil total $\mathrm{Cd}$ and liming in the soil amended with phosphate rock (PR), triple superphosphate (TSP), or $\mathrm{CdCl}_{2}$ in 2000 . 
Table 2. Comparison of Cd uptake coefficient (UC)z for cucumber vine and fruit and soil Cd extractability in DTPA as affected by $\mathrm{Cd}$ sources

\begin{tabular}{lccc}
\hline Cd source & Vine UC $(\mathrm{Cd})$ & Fruit UC $(\mathrm{Cd})$ & DTPA-Cd \\
\hline 1999 & & & \\
$\mathrm{PR}$ & 1.934 & 0.812 & 0.207 \\
$\mathrm{TSP}$ & 2.090 & 0.933 & 0.572 \\
$\mathrm{CdCl}_{2}$ & 1.731 & 0.648 & 0.754 \\
& $\mathrm{NS}$ & $\mathrm{NS}$ & $*$ \\
2000 & & & \\
$\mathrm{PR}$ & 2.246 & 1.059 & 0.232 \\
$\mathrm{TSP}$ & 1.092 & 0.647 & 0.402 \\
$\mathrm{CdCl}_{2}$ & 1.457 & 0.461 & 0.689 \\
& NS & NS & $* *$ \\
\hline
\end{tabular}

$\overline{\mathrm{z}} \mathrm{UC}$ calculated based on soil total $\mathrm{Cd}$

ss,****Nonsignificant or significant at $P=0.05$ or 0.01 , respectively.
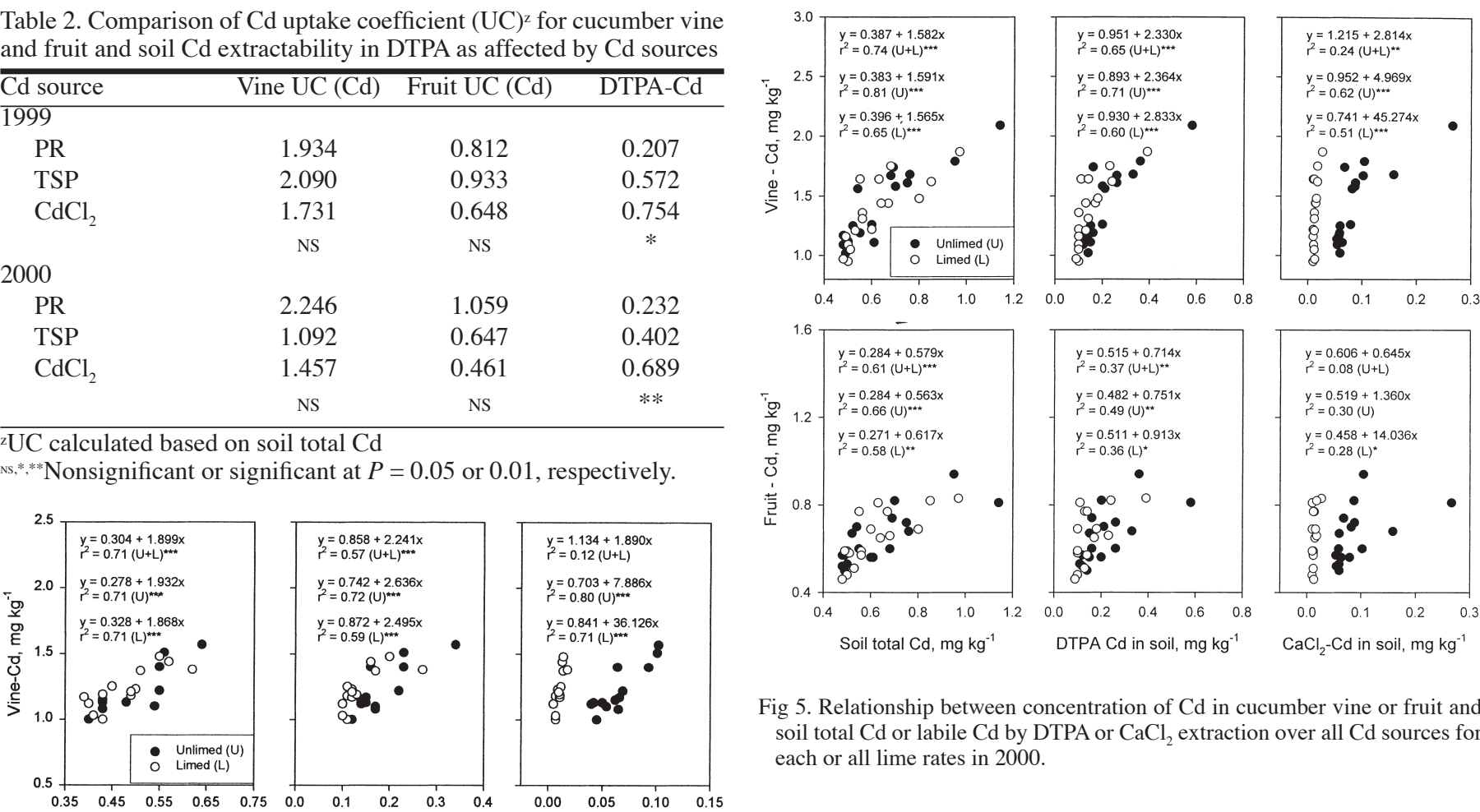

Fig 5. Relationship between concentration of $\mathrm{Cd}$ in cucumber vine or fruit and soil total $\mathrm{Cd}$ or labile $\mathrm{Cd}$ by DTPA or $\mathrm{CaCl}_{2}$ extraction over all Cd sources for each or all lime rates in 2000 .

\section{Conclusions}

Addition of the PR and TSP fertilizers at high rates increased soil total $\mathrm{Cd}, \mathrm{Cd}$ extractable by DTPA or $\mathrm{CaCl}_{2}$, and $\mathrm{Cd}$ accumulation by cucumber vine and fruit. However, only a very small fraction of $\mathrm{Cd}$ added was accumulated by the vines and fruit, and the majority of accumulated $\mathrm{Cd}$ resided in the vines. Increased soil accumulation of $\mathrm{Cd}$ over time should be expected from the applications of the fertilizers, particularly at high application rates and with vine residue returned to the soil.

Unlike leafy vegetable crops, cucumber vines and fruit accumulated $\mathrm{Cd}$ from the soil independent of $\mathrm{pH}$ or $\mathrm{Cd}$ source. This unique characteristic makes the $\mathrm{Cd}$ transfer efficiency better measured with soil total $\mathrm{Cd}$ than with the amount of labile $\mathrm{Cd}$ by DTPA for cucumber. It is unclear how the plant controlled the uptake of $\mathrm{Cd}$ and further research is needed to clarify this.

Fig 6. Uptake of $\mathrm{Cd}$ in cucumber vine or fruit or vine plus fruit as affected by the total amount of $\mathrm{Cd}$ in the surface soil amended with phosphate rock (PR), triple superphosphate (TSP), or $\mathrm{CdCl}_{2}$ in 1999. al., 2001) was not similarly found for this plant. This is attributed to the lack of $\mathrm{pH}$ and $\mathrm{Cd}$ source effects on $\mathrm{Cd}$ accumulation by the plant, as mentioned earlier.

The UC(Cd) may also be measured based on the amount of labile $\mathrm{Cd}$ by DTPA or $\mathrm{CaCl}_{2}$ extraction (Kuo et al., 2001; Smilde et al., 1992). Because there was a lower correlation of vine- or fruit-Cd with DTPA- or $\mathrm{CaCl}_{2}-\mathrm{Cd}$ than with soil total Cd (Figs. 2 and 3 ), it was not advantageous to measure $\mathrm{UC}(\mathrm{Cd})$ based on the amount of labile $\mathrm{Cd}$ in the soil for cucumber. As the advantage has been demonstrated for lettuce (Kuo et al., 2001; Smilde et al., 1992), corn (Smilde et al., 1992) and ryegrass (Kiekens et al., 1984), it follows that crop species is a factor to be considered in deciding which index of soil $\mathrm{Cd}$ availability, total or labile $\mathrm{Cd}$, should be used for measuring $\mathrm{UC}(\mathrm{Cd})$.
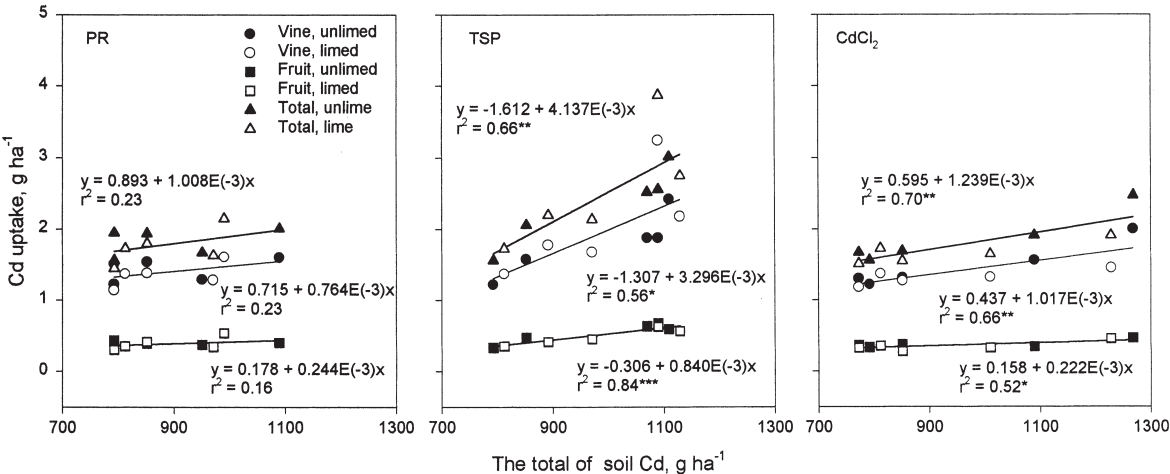

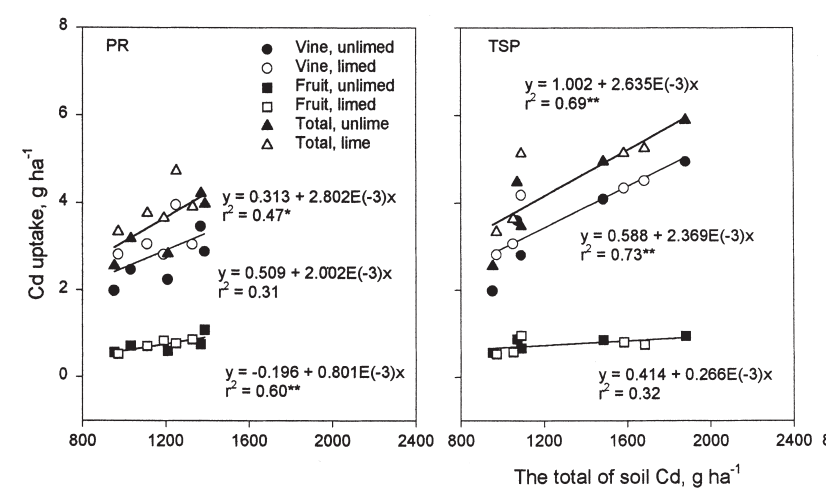

Fig 7. Uptake of Cd in cucumber vine, fruit, or vine plus fruit as affected by the total amount of $\mathrm{Cd}$ in the surface soil amended with phosphate rock (PR), triple superphosphate (TSP), or $\mathrm{CdCl}_{2}$ in 2000 .

\section{Literature Cited}

Adriano, D.C. 1986. Trace elements in the terrestrial environment. Springer-Verlag, New York.

Armiger, W.H. and M. Fried. 1957. The plant availability of various sources of phosphate rock. Soil Sci. Soc. Amer. Proc. 21:183-188.

Bell, P.F., B.R. James, and R.L. Chaney. 1991. Heavy metal extractability in long-term sewage sludge and metal salt-amended soils. J. Environ. Qual. 20:481-486.

Chaney, R.L., S.B. Sterrett, M.C. Morella, and C.A. Lloyd. 1982. Effect of sludge quality and rate, soil $\mathrm{pH}$, and time on heavy metal residues in leafy vegetables, p. 445-458. In: Proc. 5th Annu. Conf. Applied Research and Practice on Municipal and Industrial Waste. Univ. Wis., Madison,.

Crews, H.M. and B.E. Davies. 1985. Heavy metal uptake from contaminated soils by six varieties of lettuce (Lactuca sativa L.). J. Agr. Sci. Camb. 105: 591-595.

Eriksson, J. 1990. The influence of pH, soil type and time on adsorption and uptake by plants of $\mathrm{Cd}$ added to the soil. Water, Air, and Soil Pollut. 48:61-65.

Falahi-Ardakani, A., K.A. Corey, and F.R. Gouin. 1988. Influence of pH on cadmium and zinc concentrations of cucumber grown in sewage sludge. HortScience 23:1015-1017.

Grant, C.A. and L.D. Bailey. 1998. Nitrogen, phosphorus and zinc management effects on grain yield and cadmium concentration in two cultivars of durum wheat. Can. J. Plant Sci. 78:63-70.

Grant, C.A., W.T. Buckley, L.D. Bailey, and F. Selles. 1998. Cadmium accumulation in crops. Can. J. Plant Sci. 78:1-17.

Guttormsen, G., B.R. Singh, and A.S. Jeng. 1995. Cadmium concentration in vegetable crops grown in a sandy soil as affected by Cd levels in fertilizer and soil pH. Fert. Res. 41:27-32.

He, Q.B. and B.R. Singh. 1994. Crop uptake of cadmium from phosphorus fertilizers. II. Relationship with extractable soil cadmium. Water, Air, and Soil Pollut. 74:251-265.

Heckman, J.R., J.S. Angle, and R.L. Chaney. 1987. Residual effects of sewage sludge on soybean: I. Accumulation of heavy metals. J. Environ. Qual. 16:113-117.

Iretskaya, S.N., S.H. Chien, and R.G. Menon. 1998. Effect of acidulation of high cadmium containing phosphate rocks on cadmium uptake by upland rice. Plant and Soil 201:183-188.

Kiekens, L., A. Cottenie, and G. Van Landschoot. 1984. Chemical activity and biological effect of sludge-borne heavy metals and inorganic metal salts added to soils. Plant and Soil 79:89-99.

Kim, S.J., A.C. Chang, A.L. Page, and J.E. Warneke. 1988. Relative concentrations of cadmium and zinc in tissue of selected food plants grown on sludge-treated soils. J. Environ. Qual. 17:568-573.

Krishnamurti, G.S.R., G. Cieslinski, P.M. Huang, and K.C.J. Van Rees.
1997. Kinetics of cadmium release from soils as influenced by organic acids: Implication in cadmium availability. J. Environ. Qual. 26:271-277.

Kuo, S., E.J. Jellum, and A.S. Baker. 1985. Effects of soil type, liming, and sludge application on zinc and cadmium availability to Swiss chard. Soil Sci. 139:122-130.

Kuo, S., J.B. Harsh, W.L. Pan, and R.G. Stevens. 2001. Influence of metal rates and form on crop productivity and metal uptake in some Washington soils. Rpt. Wash. State Dept. Agr., Olympia.

McLaughlin, M.J., K.G. Tiller, R. Naidu, and D.P. Stevens. 1996. Review: The behavior and environmental impact of contaminants in fertilizers. Austral. J. Soil Res. 34:1-54.

Mench, M. and E. Martin. 1991. Mobilization of cadmium and other metals from two soils by root excudates of Zea mays L., Nicotiana tabacum L., and Nicotiana rustica L. Plant and Soil. 132:187-196.

Moreno-Caselles, J., R. Moral, A. Pérez-Espinosa, and M.D. PérezMurcia. 2000. Cadmium accumulation and distribution in cucumber plant. J. Plant Nutr. 23:243-250.

Mortvedt, J.J. 1985. Plant uptake of heavy metals in zinc fertilizers made from industrial by-products. J. Environ. Qual. 14:424-427.

Mortvedt, J.J. 1987. Cadmium levels in soils and plants from some long-term soil fertility experiments in the United States of America. J. Environ. Qual. 16:137-142.

Mortvedt, J.J., D.A. Mays, and G. Osborn. 1981. Uptake by wheat of cadmium and other heavy metal contaminants in phosphate fertilizers. J. Environ. Qual. 10:193-197.

Mulla, D.J., A.L. Page, and T.J. Ganje. 1980. Cadmium accumulations and bioavailability in soils from long-term phosphorus fertilization. J. Environ. Qual. 9:408-412.

Murphy, J. and J.P. Riley. 1962. A modified single solution method for the determination of phosphate in natural waters. Anal. Chim. Acta 27:31-36.

Nicholson, F.A. and K.C. Jones. 1994. Effect of phosphate fertilizers and atmospheric deposition on long-term changes in the cadmium content of soils and crops. Environ. Sci. Technol. 28:2170-2175.

Obata, H. and M. Umebayashi. 1997. Effects of cadmium on mineral nutrient concentrations in plants differing in tolerance for cadmium. J. Plant Nutr. 20:97-105.

Raven, K.P. and R.H. Loeppert. 1997. Trace element composition of fertilizers and soil amendments. J. Environ. Qual. 26:551-557.

Reuss, J.O., H.L. Dooley, and W. Griffis. 1978. Uptake of cadmium from phosphate fertilizers by peas, radishes, and lettuce. J. Environ. Qual. 7:128-133.

SAS Institute. 1989. SAS/STAT user's guide. Version 6. vol. 2. $4^{\text {th }}$ ed. SAS Inc., Cary, N.C.

Singh, B.R., R.B. Narwal, A.S. Jeng, and A. Almas. 1995. Crop uptake and extractability of cadmium in soils naturally high in metals at different pH levels. Commun. Soil Sci. Plant Anal. 26:2123-2142.

Smilde, K.W., B. van Luit, and W. van Driel. 1992. The extraction from soil and absorption by plants of applied zinc and cadmium. Plant and Soil 143:233-238.

Tack, F.M.G., J. Esteban-Mozo, and M.G. Verloo. 1998. Cadmium uptake by cucumber plants as affected by fluctuations in nutrient solution cadmium concentration during growth. Commun. Soil Sci. Plant Anal. 29:3015-3021.

United States Environmental Protection Agency. 1986. Acid digestion of sediments, sludges, and soils, p. 30501-30594. In: Test methods for evaluating solid waste. $3^{\text {rd }}$ ed. USEPA SW-S846. U.S. Gov. Print Office. Wash., D.C.

Washington State Department of Agriculture. 2000. Rules relating to fertilizers, minerals, and limes. Wash. State Dept. Agr., Olympia, Wash.

Williams, C.H. and D.J. David. 1973. The effect of superphosphate on the cadmium content of soils and plants. Austral. J. Soil Res. 11:43-56.

Wilson, D. 2001. Fateful harvest. HarperCollins, New York. 